\title{
Interleukin 6 Gene Polymorphisms Are Associated with Systemic Lupus Erythematosus in Koreans
}

\author{
JA-YOUNG JEON, HYOUN-AH KIM, SEUNG-HYUN KIM, HAE-SIM PARK, and CHANG-HEE SUH
}

\begin{abstract}
Objective. Interleukin 6 (IL-O) gene polymorphisms are known to play a role in chronic inflammatory disorders. We searched for polymorphisms in the $I L-6$ gene and described their pathogenic role in Korean patients with systemic lupus erythematosus (SLE).

Methods. Genomic DNA was extracted from 151 patients with SLE and 151 controls, and about 1.4 kb-sized $I L-6$ genes located between promoter region and exon 2 region were amplified by polymerase chain reaction. The promoter activity was analyzed by luciferase reporter assay in Hep3B cells and HeLa cells.

Results. We identified 4 single-nucleotide polymorphisms (SNP; $-572 \mathrm{C}>\mathrm{G},-278 \mathrm{~A}>\mathrm{C}$ in the promoter, and $330 \mathrm{~T}>\mathrm{G}$, and $334 \mathrm{~A}>\mathrm{T}$ in exon 2) and a $-373 \mathrm{~A}_{\mathrm{n}} \mathrm{T}_{\mathrm{n}}$ tract polymorphism in the $I L-6$ gene. The genotype frequency, $-373 \mathrm{~A}_{10} \mathrm{~T}_{11},-278 \mathrm{C}$, and $334 \mathrm{~T}$ allele were significantly associated with SLE $(p<0.001, p=0.03$ and $p=0.005$, respectively). Patients with SLE carrying the $-572 \mathrm{G}$ allele had anti-dsDNA more frequently $(\mathrm{p}=0.007)$. In addition, thrombocytopenia was significantly more common in patients carrying the $-278 \mathrm{C}$ allele $(\mathrm{p}=0.006)$. In the haplotype analysis, patients with SLE had more frequently haplotype HT3 $\left(\mathrm{CA}_{10} \mathrm{~T}_{11}\right.$ ATA, dominant model, $\left.\mathrm{p}=0.012\right)$ that was associated with arthritis, leukopenia, anti-dsDNA, and hypocomplementemia. Promoter reporter structures carrying the $-278 \mathrm{C}$ allele displayed significantly higher promoter activity than the -278 A allele in Hep3B cells $(\mathrm{p}<0.001)$ and HeLa cells $(\mathrm{p}<0.001)$.

Conclusion. These data suggest that $I L-6$ gene polymorphisms are associated with disease susceptibility and phenotype of SLE. In addition, promoter polymorphisms may be involved in regulation of $I L-6$ expression. (First Release Sept 15 2010; J Rheumatol 2010;37:2251-8; doi:10.3899/jrheum.100170)
\end{abstract}

Key Indexing Terms:

SYSTEMIC LUPUS ERYTHEMATOSUS

SINGLE NUCLEOTIDE POLYMORPHISM

\section{INTERLEUKIN 6} PROMOTER
Systemic lupus erythematosus (SLE) is an autoimmune disease characterized by dysregulation of the immune system, involving the hyperactivity of $\mathrm{T}$ cell and $\mathrm{B}$ cell, elevated production of pathogenic autoantibodies, complement activation, and the formation of immune complexes causing multiorgan damage by deposition in host tissue ${ }^{1}$. A multifactorial interaction between genetic and environmental factors may be involved. Women of African American, Hispanic, and Asian ethnicity appear to have a higher risk of SLE, and a strong familial aggregation, with a much higher

From the Department of Allergy and Rheumatology, and BK21 Division of Cell Transformation and Restoration, Ajou University School of Medicine, Suwon, Republic of Korea.

Supported by the Brain Korea 21 project for Ajou University School of Medicine.

J-Y. Jeon, MS; H-A. Kim, MD; S-H. Kim, PhD; H-S. Park, MD, PhD;

C-H. Suh, MD, PhD, Department of Allergy and Rheumatology, and BK21 Division of Cell Transformation and Restoration, Ajou University School of Medicine.

Address correspondence to Dr. C-H. Suh, Associate Professor, Ajou University School of Medicine, Department of Allergy and Rheumatology, and BK21 Division of Cell Transformation and Restoration, Ajou University School of Medicine, Woncheon-dong, San5, Youngtong-gu, Suwon, Republic of Korea 443-721.E-mail: chsuh@ajou.ac.kr Accepted for publication July 21, 2010. frequency among first-degree relatives. The concordance of the disease in identical twins is approximately 25-50\%, while it is around $2-5 \%$ in dizygotic twins ${ }^{2,3}$. These findings suggest that genetic factors play an important role in predisposition to the disease $e^{4,5}$.

Interleukin 6 (IL-6) is a multifunctional cytokine involved in regulation of the acute inflammatory response as well as modulation of specific immune responses including $\mathrm{B}$ cell and $\mathrm{T}$ cell differentiation $6,7,8$. B cell hyperactivity, elevated production of autoantibodies, and overexpression of $\mathrm{T}_{\mathrm{H}} 2$ cell cytokines IL- 6 and IL-10 are characteristic of $\mathrm{SLE}^{9,10}$. In a previous study, we found that patients with SLE had higher serum IL-6, IL-10, IL-12, and interferon- $\gamma$ levels, but lower serum IL-2 levels than controls ${ }^{11}$. In addition, the serum IL-6 level was significantly elevated in patients with active SLE and correlated with the SLE Disease Activity Index (SLEDAI), erythrocyte sedimentation rate, and C-reactive protein (CRP). IL-6 overexpression in SLE could result from an abundance of upregulating factors and/or polymorphisms in regions having gene regulatory implications. The $I L-6$ gene is located on the short arm of chromosome $7 \mathrm{p} 21$ and organized in 5 exons and 4 introns. To date, several studies have been published suggesting that Personal non-commercial use only. The Journal of Rheumatology Copyright (c) 2010. All rights reserved. 
the $I L-6$ gene polymorphism is associated with susceptibility and outcome of a variety of acute and chronic inflammatory diseases, including rheumatoid arthritis ${ }^{12}$, diabetes mellitus $^{13}$, atherosclerosis ${ }^{14}$, Alzheimer disease ${ }^{15}$, and juvenile chronic polyarthritis ${ }^{16}$.

Although several genetic association studies of the IL-6 gene polymorphisms with SLE have been reported, most of them have focused on 2 common polymorphisms, such as $-174 \mathrm{G}>\mathrm{C}$ and variable number tandem repeat. Moreover, the possible association between $I L-6$ gene polymorphisms and SLE with functional relevance has rarely been addressed. Therefore, we investigated whether genetic polymorphisms of the IL-6 gene are associated with the pathogenesis of SLE in Koreans.

\section{MATERIALS AND METHODS}

Subjects. One hundred fifty-one patients with SLE and 151 controls were enrolled from Ajou University Hospital in Suwon, Korea. All patients satisfied at least 4 of the 1982 revised American College of Rheumatology (ACR) criteria for SLE ${ }^{17}$. The patients' medical histories were reviewed from the onset of disease until admission to the study. Clinical features of the disease as defined by ACR criteria were recorded in standardized questionnaires. The controls were chosen from the general population using a screening questionnaire, which had to indicate no history of rheumatic diseases or autoimmune disorders. All the subjects participating in this study were ethnically Korean. The study was approved by the Institutional Review Board of Ajou University Hospital and all subjects gave their informed consent.

Identification and genotyping of single-nucleotide polymorphisms (SNP). Fifty patients with SLE and 50 Korean volunteer controls were used for SNP identification. Genomic DNA was extracted from whole blood using the Puregene DNA isolation kit (Gentra Systems, Minneapolis, MN, USA). An approximately $1.4 \mathrm{~kb}$-sized $I L-6$ gene located between the promoter region and exon 2 region was amplified by polymerase chain reaction (PCR) under the following conditions: hot start at $94^{\circ} \mathrm{C}$ for $5 \mathrm{~min}$ followed by 35 cycles of $94^{\circ} \mathrm{C}$ for $30 \mathrm{~s}, 60^{\circ} \mathrm{C}$ for $40 \mathrm{~s}$, and $72^{\circ} \mathrm{C}$ for $1 \mathrm{~min} 30 \mathrm{~s}$ with a final extension at $72^{\circ} \mathrm{C}$ for $7 \mathrm{~min}$. SNP genotyping was then conducted by direct sequencing (Bionics Co., Seoul, Korea). The following primers were used for amplification and sequencing: forward primer 1: 5'-GAG ACG TTC TAC GGT GT T-3', reverse primer 1: 5'-CCG TCG AGG ATG TAC CGA-3', reverse primer 2: 5'-CCG TCG AGG ATG TAC CGA-3', respectively. A minor allele frequency of greater than 5\% was considered to indicate an SNP. Additionally, we amplified that and the detected SNP were genotyped using direct sequencing for patients with SLE $(\mathrm{n}=101)$ and controls $(\mathrm{n}=101)$.

Preparation of promoter structures. A 497 bp-sized fragment (from -492 to +5 ) of the human $I L-6$ gene was amplified by PCR amplification using either -278 A homozygous or $-278 \mathrm{C}$ homozygous human genomic DNA as a template and the following primers: (forward primer 2: 5'-CAA TGG TAC CCG CTA CCT CAG TC TCC TTT G-3'; the bold character represents the KpnI site, reverse primer 3: 5'-CAATCT CGA GCA GAA TGA GCC TCA GAC ATC-3'; the bold character represents the XhoI site). Each PCR product was subcloned separately into the KpnI-XhoI site of the pGL3-Basic luciferase reporter vector (Promega, Madison, WI, USA).

Transfection and luciferase reporter assays. Hep3B cells [hepatocellular carcinoma cell line \#58064; Korean Cell Line Bank (KCLB), Seoul, Korea] were cultured in RPMI 1640 (Invitrogen, Grand Island, NY, USA), and HeLa cells (adenocarcinoma cell line \#10002; KCLB) were cultured in high-glucose DMEM (Hyclone, Logan, UT, USA) at $37^{\circ} \mathrm{C}$ in a $5 \% \mathrm{CO}_{2}$ incubator. All media were supplemented with $10 \%$ fetal bovine serum (FBS), $1 \mathrm{mM}$ sodium pyruvate, $100 \mathrm{U} / \mathrm{ml}$ of penicillin $\mathrm{G}$, and $100 \mathrm{mg} / \mathrm{ml}$ streptomycin (Invitrogen).
Hep3B and HeLa cells were transfected using FuGENE6 (Roche, Mannheim, Germany) according to the manufacturer's instructions. Briefly, the day before the transfection, $1 \times 10^{5}$ cells per well of a 12-well plate were seeded in $1 \mathrm{ml}$ of the medium with $10 \%$ FBS. Reporter plasmid DNA $(0.5 \mu \mathrm{g})$ and $1.5 \mu 1$ of FuGENE6 reagent were added to $50 \mu 1$ medium without FBS and antibiotics, mixed gently and incubated at room temperature for $15 \mathrm{~min}$ and then added to cells that had attained 50-80\% confluence in 12-well plates containing $400 \mu 1$ of medium without FBS and antibiotics. The pGL3-Control and the promoter-less pGL3-Basic vectors (Promega) were used as the positive and negative controls, respectively. Transfection efficiency was determined by measuring B-galactosidase activity assay after cotransfection of both constructors, reporter construct, and pSV-ß-galactosidase control vector into the cell line. After incubation for $5 \mathrm{~h}$, the medium was added with $500 \mu 1$ of fresh medium with $20 \%$ FBS, and the cells were incubated a further $24 \mathrm{~h}$ for Hep3B and HeLa cells at $37 \mu 1$ in a $5 \% \mathrm{CO}_{2}$ incubator.

A luciferase reporter assay was performed following the protocol supplied by the manufacturer (Promega). Cells were lysed with $100 \mu 1$ of reporter lysis buffer per well. From $100 \mu 1$ of the cell lysate, $20 \mu 1$ were assayed for luciferase activity using a luminometer, the TD-20/20 (Turner BioSystems, Sunnyvale, CA, USA). Assays were conducted in triplicate, and the experiments were repeated at least 3 times.

Statistical analysis. The genotype frequency was tested for significant departures from Hardy-Weinberg equilibrium at each SNP by chi-squared analysis. Differences in genotype frequency between the case and control were tested by the chi-squared test and calculation of the OR and the $95 \%$ CI. Three logistic regression models (codominant, dominant, and recessive) were used to analyze the SNP after controlling for age and sex as covariates. Differences in the mean value of the phenotypic characteristics between groups were compared by an ANOVA test and a t-test. P values of $<0.05$ were considered to be significant. Haplotypes were analyzed using Arlequin version 3.1 software (CMPG, Bern, Switzerland). Statistical analyses were conducted using the SPSS version 11.5 software (SPSS Inc., Chicago, IL, USA).

\section{RESULTS}

Clinical characteristics of the study subjects. The clinical characteristics of the subjects are summarized in Table 1.

Table 1. Clinical characteristics of the study subjects.

\begin{tabular}{lccc}
\hline Characteristics & $\begin{array}{c}\text { SLE, } \\
\mathrm{n}=151(\%)\end{array}$ & $\begin{array}{c}\text { Controls, } \\
\mathrm{n}=151(\%)\end{array}$ & $\begin{array}{c}\text { SLE vs } \\
\text { Controls, } \mathrm{p}\end{array}$ \\
\hline Age, yrs, mean $\pm \mathrm{SD}$ & $34.21 \pm 12.35$ & $26.16 \pm 4.27$ & 0.001 \\
Men & $28(18.5)$ & $34(22.5)$ & 0.393 \\
Women & $123(81.5)$ & $117(77.5)$ & \\
Oral ulcer & $72(47.7)$ & & \\
Arthritis & $102(67.5)$ & & \\
Serositis & $24(15.9)$ & & \\
Rash & $68(45.0)$ & & \\
Nephritis & $51(33.8)$ & & \\
Leukopenia & $92(60.9)$ & & \\
Lymphopenia & $139(92.1)$ & & \\
Thrombocytopenia & $37(24.5)$ & & \\
Anti-dsDNA & $108(71.5)$ & & \\
Hypocomplementemia & $114(75.5)$ & & \\
Anticardiolipin antibody & $63(41.7)$ & & \\
Major organ involvement & $69(45.7)$ & & \\
C-reactive protein (mg/dl, & $0.063 \pm 0.121$ & & \\
$\quad$ mean \pm SD) & & & \\
\hline
\end{tabular}

SLE: systemic lupus erythematosus. 
The mean age of the patients with SLE was $34.2 \pm 12.4$ years and $81.5 \%$ were women. The mean age of the controls was $26.2 \pm 4.3$ years and $77.5 \%$ were women. The patients with SLE were significantly older than the controls $(\mathrm{p}=$ $0.001)$; therefore, the data were analyzed with logistic regression analysis to control for age. Major organ involvements, nephritis, severe thrombocytopenia, pneumonitis, myocarditis, and gastrointestinal were positive in 69 patients with SLE (45.7\%).

SNP discovery of the IL-6 gene. Based on an allele frequency of greater than 5\%, $4 \mathrm{SNP}$ of the $I L-6$ gene were identified: $-572 \mathrm{C}>\mathrm{G},-278 \mathrm{~A}>\mathrm{C}, 330 \mathrm{~T}>\mathrm{G}$, and $334 \mathrm{~A}>\mathrm{T}$ (Figure 1A). In addition, there was a $-373 \mathrm{~A}_{\mathrm{n}} \mathrm{T}_{\mathrm{n}}$ tract polymorphism in the promoter region of the $I L-6$ gene. However, there was no polymorphism in the -174 position, which is the most commonly reported SNP in whites.

Genotype and haplotype frequencies of the IL-6 gene. The allele and genotype frequencies of the IL-6 polymorphisms are presented in Tables 2 and 3. The genotype distributions of all polymorphisms were consistent with Hardy-Weinberg equilibrium in patients with SLE and controls $(p>0.05)$. In the $-278 \mathrm{~A}>\mathrm{C}$ polymorphism, the genotype frequency of the homozygous minor allele was significantly higher in the patients with SLE when compared to the controls ( $\mathrm{p}=0.03$ for the recessive model, OR 1.779, CI 1.057-2.994; Table 2). In addition, the minor allele of the $334 \mathrm{~A}>\mathrm{T}$ polymorphism was frequently associated with SLE ( $\mathrm{p}=0.005$ for codominant model, OR 2.188, 95\% CI 1.267-3.774).

In the $-373 \mathrm{~A}_{\mathrm{n}} \mathrm{T}_{\mathrm{n}}$ tract polymorphism, the genotype frequency of $-373 \mathrm{~A}_{10} \mathrm{~T}_{11}$ was higher in patients with SLE than in the controls ( $\mathrm{p}<0.001$, OR $3.535,95 \%$ CI 1.839-6.794; Table 3). However, patients with SLE had a lower -373 $\mathrm{A}_{10} \mathrm{~T}_{10}$ genotype frequency $(\mathrm{p}=0.038, \mathrm{OR} 0.579,95 \% \mathrm{CI}$ 0.345-0.97).

Linkage disequilibrium was examined between SNP and locus by locus. Only 2 genetic polymorphisms of the $I L-6$ gene, $330 \mathrm{~T}>\mathrm{G}$ and $334 \mathrm{~A}>\mathrm{T}$, were in linkage disequilibrium $\left(\left|\mathrm{D}^{\prime}\right|=1\right.$ and $\mathrm{r}^{2}=0.023$; Figure $\left.1 \mathrm{~B}\right)$, and 4 common haplotypes for 4 polymorphisms were constructed using the Arlequin software: HT1 $\left(\mathrm{CA}_{10} \mathrm{~T}_{10} \mathrm{ATA}\right), \mathrm{HT} 2\left(\mathrm{GA}_{10} \mathrm{~T}_{10} \mathrm{ATA}\right)$,

\section{A. Schematic representation of $I L 6$ gene}

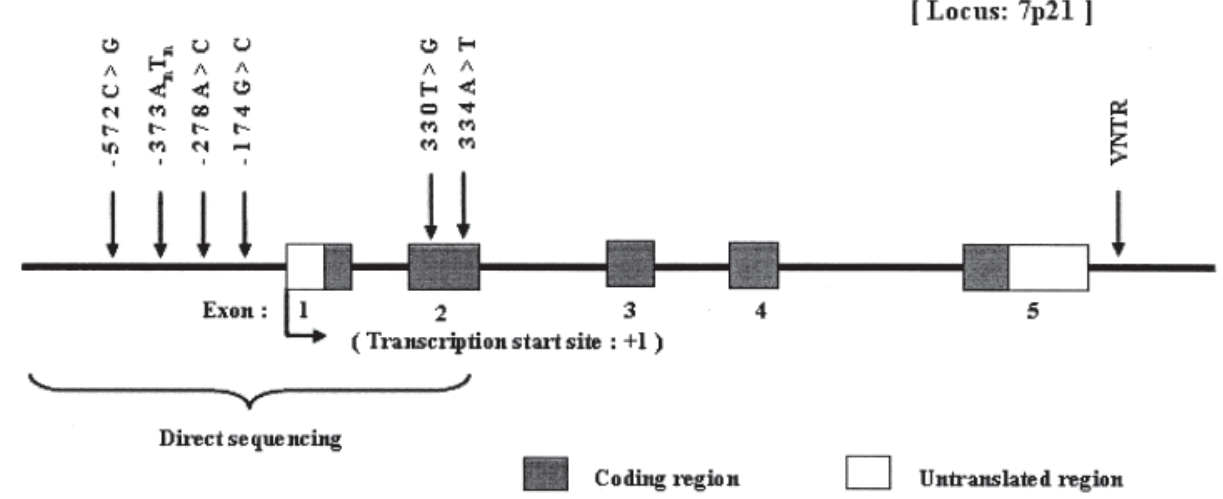

B. Linkage disequilibrium coefficients $\left(\left|\mathrm{D}^{\prime}\right|\right.$ and $\left.\mathrm{r}^{2}\right)$ among IL6 polymorphisms

\begin{tabular}{cccc}
\hline Loci l & Loci 2 & $\mathrm{D}^{\prime}$ & $\mathrm{r}^{2}$ \\
\hline$-572 \mathrm{C}>\mathrm{G}$ & $-278 \mathrm{~A}>\mathrm{C}$ & 0.109 & 0.006 \\
$-572 \mathrm{C}>\mathrm{G}$ & $330 \mathrm{C}>\mathrm{G}$ & 0.016 & 0.000 \\
$-572 \mathrm{C}>\mathrm{G}$ & $334 \mathrm{~A}>\mathrm{T}$ & 0.116 & 0.001 \\
$-278 \mathrm{~A}>\mathrm{C}$ & $330 \mathrm{~T}>\mathrm{G}$ & 0.205 & 0.020 \\
$-278 \mathrm{~A}>\mathrm{C}$ & $334 \mathrm{~A}>\mathrm{T}$ & 0.743 & 0.026 \\
$330 \mathrm{~T}>\mathrm{G}$ & $334 \mathrm{~A}>\mathrm{T}$ & 1.000 & 0.023 \\
$373 \mathrm{AnTn}$ & $-572 \mathrm{C}>\mathrm{G}$ & 0.064 & 0.000 \\
$373 \mathrm{AnTn}$ & $-278 \mathrm{~A}>\mathrm{C}$ & 0.086 & 0.000 \\
$373 \mathrm{AnTn}$ & $330 \mathrm{C}>\mathrm{G}$ & 0.151 & 0.048 \\
$373 \mathrm{AnTn}$ & $334 \mathrm{~A}>\mathrm{T}$ & 0.209 & 0.000 \\
\hline
\end{tabular}

Extension to multi-allelic marker loci is straightforward;

$$
D_{m}^{\prime}=\sum_{i=1}^{a_{i}} \sum_{k=1}^{b_{k}} p_{i} p_{k}\left|D_{A i B k}^{\prime}\right|
$$$$
R=\frac{\sum_{i=1}^{a_{i}} \sum_{k=1}^{b_{k}} D_{A i B k}^{2}}{\left(1-\sum_{i=1}^{a_{i}} p_{A i}^{2}\right)\left(1-\sum_{k=1}^{b_{k}} p_{B k}^{2}\right)}
$$

Figure 1. A. The $I L-6$ gene consists of 5 exons separated by 4 introns. Filled boxes denote translated regions and open boxes are untranslated regions. Arrows mark single-nucleotide polymorphisms within the $I L-6$ locus. Location numbers are relative to the transcription starting site. B. Linkage disequilibrium by Arlequin software with permutation test using the expectation maximization algorithm ${ }^{35,36}$. 
Table 2. The genotype and allele frequencies of polymorphisms in the promoter region and exon2 region of the IL-6 gene. Logistic regression analysis was applied to control for age and sex as covariables. Each p value was calculated with codominant (co), dominant (do), and recessive (re) models. p values in q rows were analyzed by chi-square test.

\begin{tabular}{|c|c|c|c|c|c|}
\hline \multirow[t]{2}{*}{ Loci } & \multirow[t]{2}{*}{ Genotype } & \multirow{2}{*}{$\begin{array}{c}\text { Patients with } \\
\text { SLE, } \\
\mathrm{n}=151(\%)\end{array}$} & \multirow{2}{*}{$\begin{array}{c}\text { Controls, } \\
\mathrm{n}=151(\%)\end{array}$} & \multicolumn{2}{|c|}{ SLE vs Controls } \\
\hline & & & & $\mathrm{p}$ & OR $(95 \% \mathrm{CI})$ \\
\hline \multirow[t]{4}{*}{$-572 \mathrm{C}>\mathrm{G}$} & $\mathrm{CC}$ & $74(49.0)$ & $76(50.3)$ & co: 0.470 & $1.143(0.795 \sim 1.643)$ \\
\hline & CG & $55(36.4)$ & $61(40.4)$ & do: 0.715 & $1.047(0.817 \sim 1.343)$ \\
\hline & GG & $22(14.6)$ & $14(9.3)$ & re: 0.334 & $1.211(0.822 \sim 1.786)$ \\
\hline & $\mathrm{q}$ & 0.328 & 0.295 & 0.540 & $1.062(0.878 \sim 1.282)$ \\
\hline \multirow[t]{4}{*}{$-278 \mathrm{~A}>\mathrm{C}$} & AA & $108(71.5)$ & $104(68.9)$ & co: 0.325 & $1.229(0.815 \sim 1.852)$ \\
\hline & $\mathrm{AC}$ & $28(18.5)$ & $41(27.2)$ & do: 0.945 & $1.008(0.768 \sim 1.290)$ \\
\hline & $\mathrm{CC}$ & $15(9.9)$ & $6(4.0)$ & re: 0.030 & $1.779(1.057 \sim 2.994)$ \\
\hline & $\mathrm{q}$ & 0.199 & 0.175 & 0.226 & $1.148(0.553 \sim 1.437)$ \\
\hline \multirow[t]{4}{*}{$330 \mathrm{~T}>\mathrm{G}$} & $\mathrm{TT}$ & $117(77.5)$ & $125(82.8)$ & co: 0.220 & $1.473(0.794 \sim 2.732)$ \\
\hline & TG & $34(22.5)$ & $26(17.2)$ & do: 0.220 & $1.214(0.891 \sim 1.653)$ \\
\hline & GG & $0(0)$ & $0(0)$ & re: NA & NA \\
\hline & $\mathrm{q}$ & 0.113 & 0.086 & 0.248 & $1.188(0.887 \sim 1.587)$ \\
\hline \multirow[t]{4}{*}{$334 \mathrm{~A}>\mathrm{T}$} & AA & $85(56.3)$ & $115(76.2)$ & co: 0.005 & $2.188(1.267 \sim 3.774)$ \\
\hline & AT & $65(43.0)$ & $36(23.8)$ & do: 0.005 & $1.478(1.123 \sim 1.945)$ \\
\hline & $\mathrm{TT}$ & $1(0.7)$ & $0(0)$ & re: 1.000 & 0 \\
\hline & $\mathrm{q}$ & 0.222 & 0.119 & 0.011 & $1.374(0.518 \sim 1.754)$ \\
\hline
\end{tabular}

SLE: systemic lupus erythematosus; q: minor allele frequency; NA: not applicable.

Table 3. The genotype frequencies of $-373 \mathrm{~A}_{\mathrm{n}} \mathrm{T}_{\mathrm{n}}$ polymorphism in the promoter region of $I L-6$ gene. Genotype identified by direct sequencing. Logistic regression analysis was applied to control for age and sex as covariables.

\begin{tabular}{lccccc}
\hline $\begin{array}{l}\text { Loci } \\
\left(-373 \mathrm{~A}_{\mathrm{n}} \mathrm{T}_{\mathrm{n}}\right)\end{array}$ & Genotype & $\begin{array}{c}\text { Patients with } \\
\text { SLE, } \\
\mathrm{n}=151(\%)\end{array}$ & $\begin{array}{c}\text { Controls, } \\
\mathrm{n}=151(\%)\end{array}$ & $\mathrm{p}$ & $\begin{array}{c}\text { SLE vs Controls } \\
\text { OR }(95 \% \mathrm{CI})\end{array}$ \\
\hline$-373 \mathrm{~A}_{9} \mathrm{~T}_{11}$ & $\mathrm{~A}_{9} \mathrm{~T}_{11}$ & $21(13.9)$ & $28(18.5)$ & 0.116 & $0.577(0.290 \sim 1.145)$ \\
& $\mathrm{Other}^{2}$ & $130(86.1)$ & $123(81.5)$ & & \\
$-373 \mathrm{~A}_{10} \mathrm{~T}_{10}$ & $\mathrm{~A}_{10} \mathrm{~T}_{10}$ & $82(54.3)$ & $104(68.9)$ & 0.038 & $0.579(0.345 \sim 0.970)$ \\
& Other & $69(45.7)$ & $47(31.1)$ & & \\
$-373 \mathrm{~A}_{10} \mathrm{~T}_{11}$ & $\mathrm{~A}_{10} \mathrm{~T}_{11}$ & $48(31.8)$ & $19(12.6)$ & $<0.001$ & $3.535(1.839 \sim 6.794)$ \\
& Other & $103(68.2)$ & $132(87.4)$ & & \\
\hline
\end{tabular}

IL-6: interleukin 6; SLE: systemic lupus erythematosus.

HT3 $\left(\mathrm{CA}_{10} \mathrm{~T}_{11} \mathrm{ATA}\right)$, and HT4 $\left(\mathrm{CA}_{10} \mathrm{~T}_{10} \mathrm{ATT}\right.$; Table 4). There was significant difference between patients with SLE and controls in the observed haplotype HT3 (dominant model, $\mathrm{p}=0.012$ ).

Associations between SLE phenotype and SNP. The clinical characteristics according to genotype are summarized in Table 5. In the $-572 \mathrm{C}>\mathrm{G}$ polymorphism, anti-dsDNA was significantly more common in the patients with SLE who had the $-572 \mathrm{G}$ allele $(\mathrm{p}=0.007)$. In addition, the incidence of thrombocytopenia was significantly higher in patients with SLE who carried the $-278 \mathrm{C}$ allele $(\mathrm{p}=0.006)$. No association with SLE phenotypes was observed when the other SNP were evaluated.

The clinical characteristics according to haplotype are summarized in Table 6. The frequency of arthritis was sig- nificantly lower in patients who had haplotype HT3 (C $\left.\mathrm{A}_{10} \mathrm{~T}_{11} \mathrm{ATA}\right)$. But the frequency of leukopenia, anti-dsDNA, and complementemia was significantly higher in patients who had haplotype HT3.

Promoter activity of the IL-6 gene according to the -278 A $>C$ polymorphism. To determine if the IL-6 -278 A > C polymorphism is associated with altered promoter activity, 2 reporter structures composed of the promoter sequence carrying either $-278 \mathrm{~A}$ or $-278 \mathrm{C}$ and the luciferase reporter gene were transfected into the Hep3B cell line (Figure 2A). Luciferase activity of the structure containing $-278 \mathrm{C}$ was enhanced when compared to that of the structure containing $-278 \mathrm{~A}(\mathrm{p}=0.001)$. Enhanced promoter activity of the -278 $\mathrm{C}$ structure was replicated in different cell lines of the HeLa cells $(\mathrm{p}=0.001$, Figure $2 \mathrm{~B})$. 
Table 4. The haplotype frequencies of the IL-6 gene. Haplotypes (HT) were analysed using Arlequin version 3.1 software based on the expectation maximization algorithm. Logistic regression analysis was applied to control for age and sex as covariables. Each p value was calculated with codominant (co), dominant (do), and recessive (re) models.

\begin{tabular}{|c|c|c|c|c|c|}
\hline \multirow[t]{2}{*}{ Haplotype } & & \multirow{2}{*}{$\begin{array}{l}\text { Patients with SLE, } \\
\mathrm{n}=151(\%)\end{array}$} & \multirow{2}{*}{$\begin{array}{c}\text { Controls, } \\
\mathrm{n}=151(\%)\end{array}$} & \multicolumn{2}{|c|}{ SLE vs Controls } \\
\hline & & & & $\mathrm{p}$ & OR $(95 \% \mathrm{CI})$ \\
\hline \multirow[t]{3}{*}{$\mathrm{HT} 1\left[\mathrm{CA}_{10} \mathrm{~T}_{10} \mathrm{ATA}\right]$} & $+/+$ & $12(7.9)$ & $19(12.6)$ & co: 0.241 & $0.799(0.549 \sim 1.162)$ \\
\hline & $+/-$ & $51(33.8)$ & $55(36.4)$ & do: 0.486 & $0.915(0.713 \sim 1.175)$ \\
\hline & $-1-$ & $88(58.3)$ & $77(51.0)$ & re: 0.149 & $0.727(0.472 \sim 1.120)$ \\
\hline \multirow[t]{3}{*}{$\mathrm{HT} 2\left[\mathrm{GA}_{10} \mathrm{~T}_{10} \mathrm{ATA}\right]$} & $+/+$ & $1(0.7)$ & $3(2.0)$ & co: 0.380 & $0.771(0.431 \sim 1.378)$ \\
\hline & $+/-$ & $23(15.2)$ & $28(18.5)$ & do: 0.447 & $0.883(0.640 \sim 1.217)$ \\
\hline & $-1-$ & $127(84.1)$ & $120(79.5)$ & re: 0.480 & $0.655(0.203 \sim 2.118)$ \\
\hline \multirow[t]{3}{*}{ HT3 $\left[\mathrm{CA}_{10} \mathrm{~T}_{11}\right.$ ATA $]$} & $+/+$ & $10(6.6)$ & $1(0.7)$ & co: 0.093 & $1.518(0.933 \sim 2.472)$ \\
\hline & $+/-$ & $20(13.2)$ & $0(0)$ & do: 0.012 & $1.608(1.111 \sim 2.328)$ \\
\hline & $-1-$ & $121(80.1)$ & $145(96.0)$ & re: 0.990 & $1.003(0.594 \sim 1.695)$ \\
\hline \multirow[t]{3}{*}{$\mathrm{HT} 4\left[\mathrm{CA}_{10} \mathrm{~T}_{10} \mathrm{ATT}\right]$} & $+/+$ & $0(0)$ & $0(0)$ & co: 0.267 & $0.614(0.259 \sim 1.452)$ \\
\hline & $+/-$ & $12(7.9)$ & $19(12.6)$ & do: 0.267 & $0.783(0.509 \sim 1.205)$ \\
\hline & $-1-$ & $139(92.1)$ & $132(87.4)$ & re: NA & NA \\
\hline \multirow[t]{3}{*}{ Other HT } & $+/+$ & $48(31.8)$ & $40(26.5)$ & co: 0.450 & $1.128(0.825 \sim 1.544)$ \\
\hline & $+/-$ & $54(35.8)$ & $53(35.1)$ & do: 0.300 & $1.148(0.884 \sim 1.489)$ \\
\hline & $-1-$ & $49(32.4)$ & $58(38.4)$ & re: 0.817 & $1.033(0.782 \sim 1.365)$ \\
\hline
\end{tabular}

IL-6: interleukin 6; SLE: systemic lupus erythematosus; NA: not applicable.

Table 5. Comparison of the clinical characteristics according to the genotype of the $I L-6$ gene in SLE. Logistic regression analysis was applied to control for age and sex as covariables. No association with SLE phenotypes was observed when the other SNP were evaluated. Values are number (\%) unless otherwise indicated.

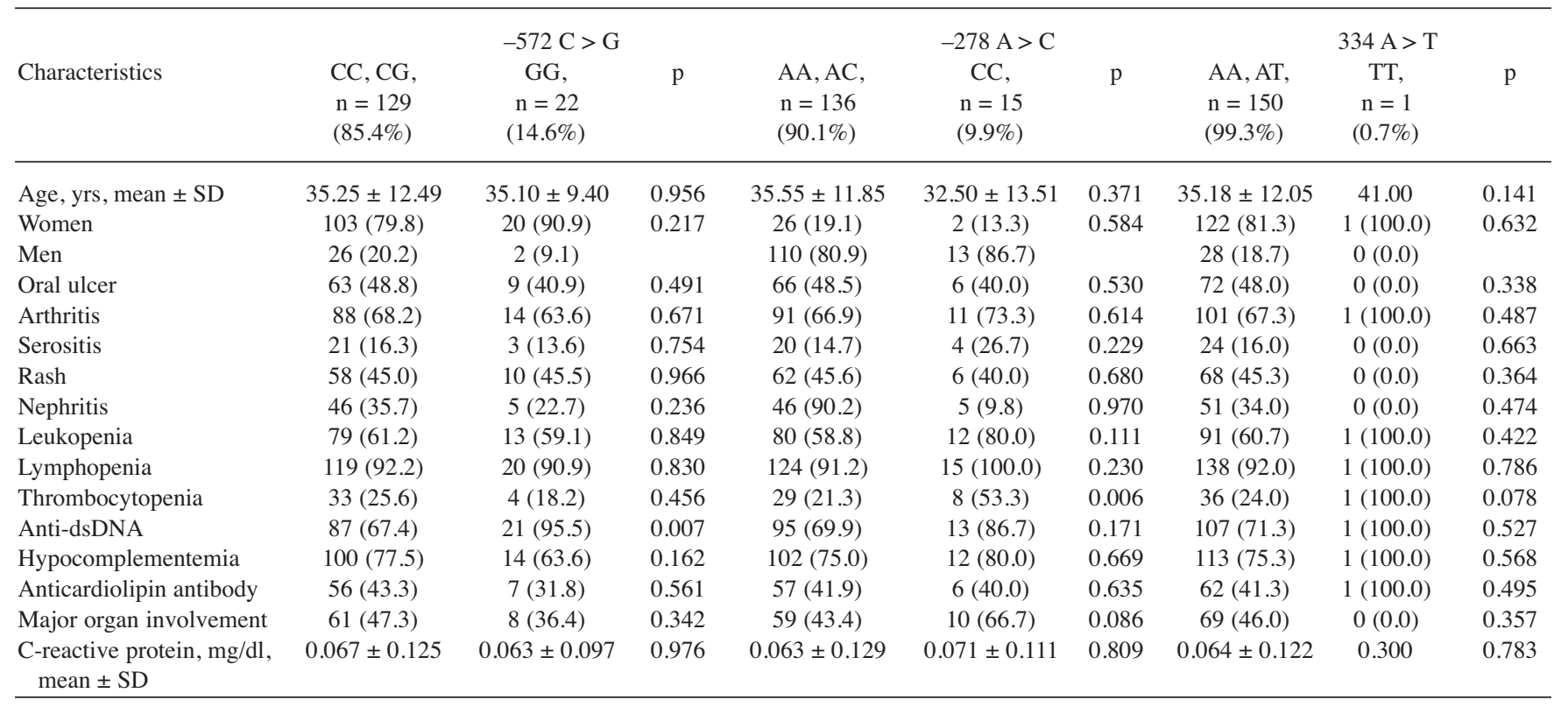

IL-6: interleukin 6; SLE: systemic lupus erythematosus; SNP: single-nucleotide polymorphism.

\section{DISCUSSION}

SLE is a complex multigenic disease in which the contributing genetic systems are being rapidly identified. In human SLE, genes of early components of complements as well as many polymorphic genes (including the MHC, Fc-gamma receptors, mannose-binding protein, PCDC-1, CRP, Bcl-2, IL-1 receptor antagonist, IL-10, tumor necrosis factor- $\alpha$ genes, etc.) were found to be associated with SLE by population-based case-control studies ${ }^{18,19,20}$. Although the initiating immunological event in SLE remains unknown, it has been shown that an imbalance is involved between depressed $\mathrm{T}_{\mathrm{H}} 1$ cell cytokines, which promote cell-mediated immunity, and enhanced $\mathrm{T}_{\mathrm{H}} 2$ cell cytokines, which support physiological cascade ${ }^{21}$. Cytokines are also known to be involved in the pathogenesis of SLE. In particular, IL-6 has an important role in the regulation of immune 
Table 6. Comparison of the clinical characteristics according to the haplotype (HT) of the $I L-6$ gene in systemic lupus erythematosus (SLE). Logistic regression analysis was applied to control for age and sex as covariables. No association with SLE phenotypes was observed when the other haplotypes were evaluated. Values are number $(\%)$ unless otherwise indicated.

\begin{tabular}{|c|c|c|c|c|c|c|c|c|c|}
\hline \multirow[t]{2}{*}{ Characteristics } & \multicolumn{3}{|c|}{$\mathrm{HT} 1\left[\mathrm{CA}_{10} \mathrm{~T}_{10} \mathrm{ATA}\right]$} & \multicolumn{3}{|c|}{$\mathrm{HT} 2\left[\mathrm{GA}_{10} \mathrm{~T}_{10} \mathrm{ATA}\right]$} & \multicolumn{3}{|c|}{$\mathrm{HT} 3\left[\mathrm{CA}_{10} \mathrm{~T}_{11} \mathrm{ATA}\right]$} \\
\hline & $\begin{array}{c}+/+,+/- \\
\mathrm{n}=63 \\
(41.7 \%)\end{array}$ & $\begin{array}{c}-/- \\
\mathrm{n}=88 \\
(58.3 \%)\end{array}$ & $\mathrm{p}$ & $\begin{array}{c}+/+,+/- \\
\mathrm{n}=24 \\
(15.9 \%)\end{array}$ & $\begin{array}{c}-/- \\
\mathrm{n}=127 \\
(84.1 \%)\end{array}$ & $\mathrm{p}$ & $\begin{array}{c}+/+,+/- \\
\mathrm{n}=30 \\
(19.8 \%)\end{array}$ & $\begin{array}{c}-/- \\
\mathrm{n}=121 \\
(80.1 \%)\end{array}$ & $\mathrm{p}$ \\
\hline Age, yrs, mean \pm SD & $33.5 \pm 11.8$ & $34.7 \pm 12.8$ & 0.568 & $32.7 \pm 10.2$ & $34.5 \pm 12.7$ & 0.508 & $31.5 \pm 11.7$ & $34.9 \pm 12.5$ & 0.176 \\
\hline Women & $53(84.1)$ & $70(79.5)$ & 0.475 & $23(95.8)$ & $100(78.7)$ & 0.048 & $24(80.0)$ & $99(81.8)$ & 0.819 \\
\hline Men & $10(15.9)$ & $18(20.5)$ & & $1(4.2)$ & $27(21.3)$ & & $6(20.0)$ & $22(18.2)$ & \\
\hline Oral ulcer & $32(50.8)$ & $40(45.5)$ & 0.517 & $13(54.2)$ & $59(46.5)$ & 0.488 & $12(40.0)$ & $60(49.6)$ & 0.347 \\
\hline Arthritis & $42(66.7)$ & $60(68.2)$ & 0.845 & $14(58.3)$ & $88(69.3)$ & 0.293 & $15(50.0)$ & 87 (71.9) & 0.022 \\
\hline Serositis & $12(19.0)$ & $12(13.6)$ & 0.370 & $1(4.2)$ & $23(18.1)$ & 0.087 & $3(10.0)$ & $21(17.4)$ & 0.324 \\
\hline Rash & $31(49.2)$ & $37(42)$ & 0.383 & $10(41.7)$ & $58(45.7)$ & 0.718 & $11(36.7)$ & $57(47.1)$ & 0.304 \\
\hline Nephritis & $24(38.1)$ & $27(30.7)$ & 0.342 & $6(25.0)$ & $45(35.4)$ & 0.322 & $9(30.0)$ & $42(34.7)$ & 0.625 \\
\hline Leukopenia & $37(58.7)$ & $55(62.5)$ & 0.640 & $14(58.3)$ & $78(61.4)$ & 0.776 & $23(76.7)$ & $69(57.0)$ & 0.048 \\
\hline Lymphopenia & $60(95.2)$ & $79(89.8)$ & 0.221 & $21(87.5)$ & $118(92.9)$ & 0.369 & $29(96.7)$ & $110(90.9)$ & 0.297 \\
\hline Thrombocytopenia & $16(25.4)$ & $21(23.9)$ & 0.829 & $8(33.3)$ & $29(22.8)$ & 0.273 & $10(33.3)$ & $27(22.3)$ & 0.209 \\
\hline Anti-dsDNA & $42(66.7)$ & $66(75.0)$ & 0.263 & $18(75.0)$ & $90(70.9)$ & 0.681 & $26(86.7)$ & $82(67.8)$ & 0.040 \\
\hline Hypocomplementemia & $46(73.0)$ & $68(77.3)$ & 0.549 & $15(62.5)$ & $99(78.0)$ & 0.106 & $28(93.3)$ & $86(71.1)$ & 0.011 \\
\hline Anticardiolipin antibody & $28(44.4)$ & $35(39.8)$ & 0.566 & $9(37.5)$ & $54(42.5)$ & 0.647 & $13(43.3)$ & $50(41.3)$ & 0.842 \\
\hline Major organ involvement & $32(50.8)$ & $37(42.0)$ & 0.287 & $9(37.5)$ & $60(47.2)$ & 0.379 & $14(46.7)$ & $55(45.5)$ & 0.905 \\
\hline $\begin{array}{l}\text { C-reactive protein, } \\
\qquad \mathrm{mg} / \mathrm{dl}, \text { mean } \pm \mathrm{SD}\end{array}$ & $0.073 \pm 0.158$ & $0.057 \pm 0.087$ & 0.422 & $0.047 \pm 0.057$ & $0.067 \pm 0.130$ & 0.462 & $0.072 \pm 0.120$ & $0.061 \pm 0.122$ & 0.668 \\
\hline
\end{tabular}

SLE: systemic lupus erythematosus.

A

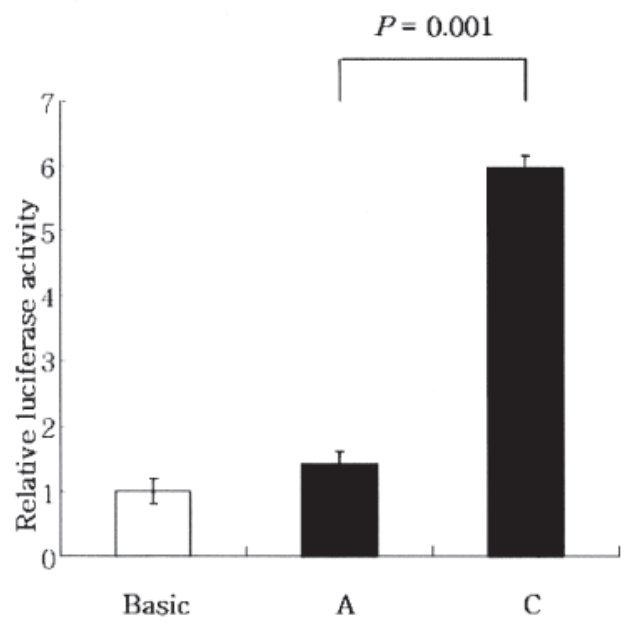

B

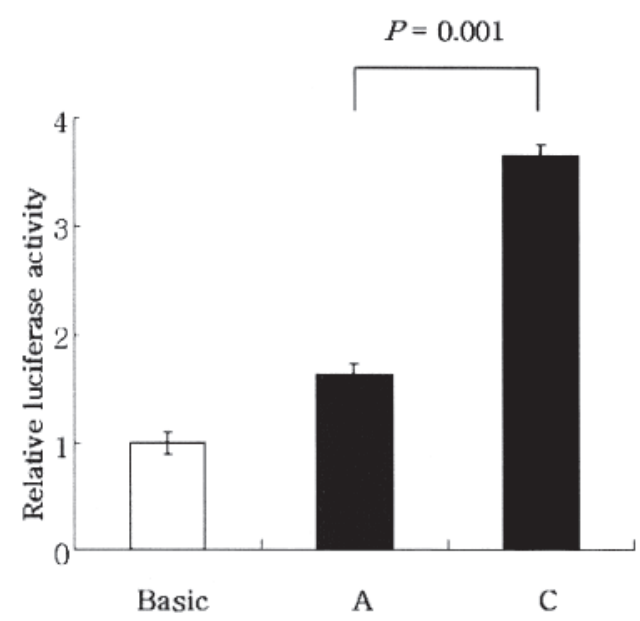

Figure 2. Effect of the $-278 \mathrm{~A}>\mathrm{C}$ polymorphism on the transcription activity of the human $I L-6$ gene promoter in Hep3B cells (A) and HeLa cells (B). Relative luciferase activity is represented as the ratio of the activity to the luciferase activity in the cells transfected with the empty control vector, pGL3-Basic. Each experiment was conducted in triplicate for each sample, and the results are expressed as the mean \pm SEM for 3 independent experiments. The $\mathrm{p}$ value was determined by a paired $\mathrm{t}$-test.

responses, by supplying positive and negative signals to activated $\mathrm{T}$ and $\mathrm{B}$ cells ${ }^{22}$.

Therefore, we conducted this case-control study of Korean patients with SLE under the assumption that genetic polymorphisms of the $I L-6$ gene may be related to the susceptibility of SLE and to its clinical manifestations. We identified 5 genetic polymorphisms $(-572 \mathrm{C}>\mathrm{G},-373$
$\mathrm{A}_{\mathrm{n}} \mathrm{T}_{\mathrm{n}},-278 \mathrm{~A}>\mathrm{C}$ in the promoter region, and $330 \mathrm{~T}>\mathrm{G}$ and $334 \mathrm{~A}>\mathrm{T}$ in the exon2 region), including 3 novel SNP $(-278 \mathrm{~A}>\mathrm{C}, 330 \mathrm{~T}>\mathrm{G}$, and $334 \mathrm{~A}>\mathrm{T})$ in the $I L-6$ gene. Further, we found that the rare allele of the $-278 \mathrm{~A}>\mathrm{C}$ and the $334 \mathrm{~A}>\mathrm{T}$ SNP, and the $-373 \mathrm{~A}_{10} \mathrm{~T}_{11}$ allele of the -373 $\mathrm{A}_{\mathrm{n}} \mathrm{T}_{\mathrm{n}}$ tract polymorphism were associated with a significantly higher disease susceptibility. Our results suggest that 
the human $I L-6$ gene plays an important role in the development of SLE.

Two promoter polymorphisms in the $I L-6$ gene were not in linkage disequilibrium. Among the polymorphisms, -278 A $>$ C promoter polymorphism was associated with genotype and phenotype (thrombocytopenia). Therefore, we focused on the functional effects of the $-278 \mathrm{~A}>\mathrm{C}$ polymorphism. To investigate the effects of the $-278 \mathrm{~A}>\mathrm{C}$ polymorphism on $I L-6$ expression, we used a functional assay of promoter activity in reporter structures that contained mutant type or polymorphic promoters in the Hep3B cell line and HeLa cell line. Because the Hep3B cell line originates from human hepatocellular carcinoma and $I L-6$ is primarily synthesized in the liver, it is an appropriate cell line for this purpose. To replicate the Hep3B cell line results, we also tested the promoter activity in the HeLa cell line from human cervical carcinoma ${ }^{21,23}$. The promoter reporter structure carrying the $-278 \mathrm{C}$ allele displayed higher promoter activity than the structure carrying the -278 A allele in Hep3B cells and HeLa cells. Characteristically, patients with SLE have elevated autoantibody production and overexpression of IL-6. These autoantibodies attack platelets and cause thrombocytopenia. Our results showed that the -278 $\mathrm{C}$ allele, which was associated with thrombocytopenia, displayed significantly higher promoter activity.

To determine if the genetic variants created a transcription factor binding site, sequences were submitted to the TFSEARCH online program, which revealed that the -278 A $>$ C polymorphism might be a potential AP-1 binding motif. Moreover, several reports have suggested that the human $I L-6$ promoter contains multiple regulatory elements such as those binding transcription factors belonging to the NF- $\mathrm{KB}, \mathrm{C} / \mathrm{EBP}$, and AP-1 families ${ }^{24,25}$. The AP-1 transcription factors are homodimers and heterodimers composed of basic region-leucine zipper proteins that belong to the Jun and Fos subfamilies. Several lines of evidence suggest that members of the AP-1 transcription factor work in concert to regulate the $I L-6$ promoter in a cell-type or inducer-specific fashion $25,26,27,28,29$. Our results indicate that the binding affinity of AP-1 may be increased in patients with SLE who carry the $-278 \mathrm{C}$ allele.

In the $334 \mathrm{~A}>\mathrm{T}$ polymorphism, the genotype frequency of the minor allele was significantly higher in the patients with SLE compared to the controls. Although this mutation did not lead to an amino acid change, we think that there might be an indirect association between this mutation and SLE.

The genotype frequency of $-373 \mathrm{~A}_{10} \mathrm{~T}_{11}$ was significantly higher in patients with SLE than in the controls. However, patients with SLE had significantly lower $-373 \mathrm{~A}_{10} \mathrm{~T}_{10}$ genotype frequencies than did the controls. These results demonstrated that $-373 \mathrm{~A}_{\mathrm{n}} \mathrm{T}_{\mathrm{n}}$ tract polymorphism was associated with the disease susceptibility of SLE. Specifically, the $-373 \mathrm{~A}_{10} \mathrm{~T}_{11}$ genotype might play an important role in
$I L-6$ expression. These findings are consistent with the results of previous studies that have shown that different $A_{n} T_{n}$ patterns influence this differential expression ${ }^{16,23}$. It is possible that individual $A_{n} T_{n}$ tract genotypes make differing contributions to $I L-6$ expression, acting to either enhance or repress transcription ${ }^{30}$.

Our results demonstrated that the $-572 \mathrm{C}>\mathrm{G}$ polymorphism was associated with anti-dsDNA positivity and that the $-278 \mathrm{~A}>\mathrm{C}$ polymorphism was associated with thrombocytopenia. These findings suggest that the disease phenotype was more common in patients with SLE who had minor allele $-572 \mathrm{C}>\mathrm{G}$ and $-278 \mathrm{~A}>\mathrm{C}$ polymorphisms than in those who had the major homozygous genotype.

In the haplotype analysis, there was significant difference between SLE and controls in the observed haplotype HT3 $\left(\mathrm{CA}_{10} \mathrm{~T}_{11} \mathrm{ATA}\right)$ that was associated with decreased arthritis, and increased leukopenia, anti-dsDNA, and complementemia. Our results suggest that patients with SLE have elevated autoantibodies that acted against leukocytes, DNA, and complements. Particularly, $-373 \mathrm{~A}_{10} \mathrm{~T}_{11}$ may have a powerful influence between HT3 and lupus phenotypes.

The most frequently investigated polymorphism is the $-174 \mathrm{G}>\mathrm{C}$ polymorphism in the promoter region of the $I L-6$ gene. In a German SLE study, $-174 \mathrm{G}>\mathrm{C}$ polymorphism did not contribute significantly to disease susceptibility, but did predispose to distinct clinical and immunological features ${ }^{20}$. In a study of Whites and African Americans, the $-174 \mathrm{G}>\mathrm{C}$ polymorphism was not associated with $\mathrm{SLE}^{31}$. Interestingly, the present study revealed that there was no $\mathrm{C}$ allele in the $-174 \mathrm{G}>\mathrm{C}$ polymorphism, which is a common polymorphism in Whites ${ }^{19}$. Our results support those of studies that have found decreased frequencies of the $\mathrm{C}$ allele in Asians such as southern Chinese coal workers with pneumoconiosis $(\mathrm{C} \text { allele } 0.20 \%)^{32}$, Japanese women with hypertension $(\mathrm{C} \text { allele } 0.0 \%)^{33}$, and Korean $\operatorname{IgA}$ nephropathy patients (C allele $0.48 \%)^{34}$. The reason for the decreased occurrence of the $\mathrm{C}$ allele is unclear; however, considering the very low frequencies of the $-174 \mathrm{C}$ allele in the Korean, Japanese, and Chinese, it likely reflects the genetic characteristic of Far East Asian populations. In addition, the major alleles of $-373 A_{n} T_{n}$ and $-572 \mathrm{C}>\mathrm{G}$ were found to be $-373 \mathrm{~A}_{10} \mathrm{~T}_{10}$ and $-572 \mathrm{C}$ in Koreans, but were $-373 \mathrm{~A}_{8} \mathrm{~T}_{12}$ and $-572 \mathrm{G}$ in other ethnic groups, which further demonstrates that genetic variations in SLE are associated with ethnic backgrounds.

It is important to note that our study has the following limitations. First, our study was performed in a single population of patients without replication. In addition, the studied population was relatively small, which likely prevented identification of small differences in the genetic susceptibility of SLE. Therefore, further studies with larger populations are needed. Second, we did not evaluate the functional effects of the $-572 \mathrm{C}>\mathrm{G}$ polymorphism. Although there was no significant difference between SLE and controls in Personal non-commercial use only. The Journal of Rheumatology Copyright (c) 2010. All rights reserved. 
genotype analysis in the case of -572, it was associated with anti-dsDNA antibody. Further studies will address the functional effects of the $-572 \mathrm{C}>\mathrm{G}$ polymorphism and the double functional effects of the $-278 \mathrm{~A}>\mathrm{C}$ and $-572 \mathrm{C}>\mathrm{G}$ polymorphism. Although the -572 and -278 were not in linkage disequilibrium, both polymorphisms were located in the promoter site, which is important for gene expression.

These data suggest that $I L-6$ genetic polymorphisms are associated with disease susceptibility and clinical manifestations of SLE in Koreans. Specifically, promoter polymorphisms may be involved in regulation of $I L-6$ expression.

\section{REFERENCES}

1. Mok CC, Lau CS. Pathogenesis of systemic lupus erythematosus. J Clin Pathol 2003;56:481-90.

2. Deapen D, Escalante A, Weinrib L, Horwitz D, Bachman B, Roy-Burman $\mathrm{P}$, et al. A revised estimate of twin concordance in systemic lupus erythematosus. Arthritis Rheum 1992;35:311-8.

3. Reichlin M, Harley JB, Lockshin MD. Serologic studies of monozygotic twins with systemic lupus erythematosus. Arthritis Rheum 1992;35:457-64.

4. Tsao BP. The genetics of human systemic lupus erythematosus. Trends Immunol 2003;24:595-602.

5. Croker JA, Kimberly RP. Genetics of susceptibility and severity in systemic lupus erythematosus. Curr Opin Rheumatol 2005; 17:529-37.

6. Naka T, Nishimoto N, Kishimoto T. The paradigm of IL6: from basic science to medicine. Arthritis Res 2002;4 Suppl 3:S233-42.

7. Papanicolaou DA, Wilder RL, Manolagas SC, Chrousos GP. The pathophysiologic roles of interleukin-6 in human disease. Ann Intern Med 1998;128:127-37.

8. Dean GS, Tyrrell-Price J, Crawley E, Isenberg DA. Cytokines and systemic lupus erythematosus. Ann Rheum Dis 2000;59:243-51.

9. Tsokos GC, Kovacs B, Liossis SN. Lymphocytes, cytokines, inflammation, and immune trafficking. Curr Opin Rheumatol 1997;9:380-6.

10. Suh CH, Kim HA. Cytokines and their receptors as biomarkers of systemic lupus erythematosus. Expert Rev Mol Diagn 2008; 8:189-98.

11. Chun HY, Chung JW, Kim HA, Yun JM, Jeon JY, Ye YM, et al. Cytokine IL6 and IL-10 as biomarkers in systemic lupus erythematosus. J Clin Immunol 2007;27:461-6.

12. Pascual M, Nieto A, Mataran L, Balsa A, Pascual-Salcedo D, Martin J. IL6 promoter polymorphisms in rheumatoid arthritis. Genes Immun 2000;1:338-40.

13. Vozarova B, Fernandez-Real JM, Knowler WC, Gallart L, Hanson RL, Gruber JD, et al. The interleukin-6 (-174) G/C promoter polymorphism is associated with type-2 diabetes mellitus in Native Americans and Caucasians. Hum Genet 2003;112:409-13.

14. Georges JL, Loukaci V, Poirier O, Evans A, Luc G, Arveiler D, et al. Interleukin-6 gene polymorphisms and susceptibility to myocardial infarction: the ECTIM study. Etude Cas-Temoin de 1'Infarctus du Myocarde. J Mol Med 2001;79:300-5.

15. Faltraco F, Burger K, Zill P, Teipel SJ, Moller HJ, Hampel H, et al. Interleukin-6-174 G/C promoter gene polymorphism $\mathrm{C}$ allele reduces Alzheimer's disease risk. J Am Geriatr Soc 2003;51:578-9.

16. Fishman D, Faulds G, Jeffery R, Mohamed-Ali V, Yudkin JS, Humphries $\mathrm{S}$, et al. The effect of novel polymorphisms in the interleukin-6 (IL6) gene on IL6 transcription and plasma IL6 levels, and an association with systemic-onset juvenile chronic arthritis. J Clin Invest 1998;102:1369-76.

17. Tan EM, Cohen AS, Fries JF, Masi AT, McShane DJ, Rothfield NF, et al. The 1982 revised criteria for the classification of systemic lupus erythematosus. Arthritis Rheum 1982;25:1271-7.

18. Nath SK, Kilpatrick J, Harley JB. Genetics of human systemic lupus erythematosus: the emerging picture. Curr Opin Immunol 2004;16:794-800.

19. Rhodes B, Vyse TJ. General aspects of the genetics of SLE. Autoimmunity 2007;40:550-9.

20. Tsao BP. Genetic susceptibility to lupus nephritis. Lupus 1998;7:585-90

21. Schotte H, Schluter B, Rust S, Assmann G, Domschke W, Gaubitz M. Interleukin-6 promoter polymorphism $(-174 \mathrm{G} / \mathrm{C})$ in Caucasian German patients with systemic lupus erythematosus. Rheumatology 2001;40:393-400.

22. Linker-Israeli M, Honda M, Nand R, Mandyam R, Mengesha E, Wallace DJ, et al. Exogenous IL-10 and IL-4 down-regulate IL6 production by SLE-derived PBMC. Clin Immunol 1999;91:6-16.

23. Terry CF, Loukaci V, Green FR. Cooperative influence of genetic polymorphisms on interleukin 6 transcriptional regulation. J Biol Chem 2000;275:18138-44.

24. Faggioli L, Costanzo C, Donadelli M, Palmieri M. Activation of the Interleukin-6 promoter by a dominant negative mutant of c-Jun. Biochim Biophys Acta 2004;1692:17-24.

25. Baccam M, Woo SY, Vinson C, Bishop GA. CD40-mediated transcriptional regulation of the IL6 gene in B lymphocytes: involvement of NF-kappa B, AP-1, and C/EBP. J Immunol 2003;170:3099-108.

26. Tuyt LM, Dokter WH, Birkenkamp K, Koopmans SB, Lummen C, Kruijer W, et al. Extracellular-regulated kinase $1 / 2$, Jun N-terminal kinase, and c-Jun are involved in NF-kappa B-dependent IL6 expression in human monocytes. J Immunol 1999;162:4893-902.

27. Grassl C, Luckow B, Schlondorff D, Dendorfer U. Transcriptional regulation of the interleukin-6 gene in mesangial cells. J Am Soc Nephrol 1999;10:1466-77.

28. Mann J, Oakley F, Johnson PW, Mann DA. CD40 induces interleukin-6 gene transcription in dendritic cells: regulation by TRAF2, AP-1, NF-kappa B, AND CBF1. J Biol Chem 2002;277:17125-38.

29. Persson E, Voznesensky OS, Huang YF, Lerner UH. Increased expression of interleukin- 6 by vasoactive intestinal peptide is associated with regulation of CREB, AP-1 and C/EBP, but not NF-kappaB, in mouse calvarial osteoblasts. Bone 2005;37:513-29.

30. Kelberman D, Fife M, Rockman MV, Brull DJ, Woo P, Humphries SE. Analysis of common IL6 promoter SNP variants and the AnTn tract in humans and primates and effects on plasma IL6 levels following coronary artery bypass graft surgery. Biochim Biophys Acta 2004;1688:160-7.

31. Linker-Israeli M, Wallace DJ, Prehn J, Michael D, Honda M, Taylor KD, et al. Association of IL6 gene alleles with systemic lupus erythematosus (SLE) and with elevated IL6 expression. Genes Immun 1999;1:45-52.

32. Zhai R, Liu G, Yang C, Huang C, Wu C, Christiani DC. The G to C polymorphism at -174 of the interleukin- 6 gene is rare in a Southern Chinese population. Pharmacogenetics 2001;11:699-701.

33. Nakajima T, Ota N, Yoshida H, Watanabe S, Suzuki T, Emi M. Allelic variants in the interleukin- 6 gene and essential hypertension in Japanese women. Genes Immun 1999;1:115-9.

34. Lim CS, Zheng S, Kim YS, Ahn C, Han JS, Kim S, et al. The -174 $\mathrm{G}$ to $\mathrm{C}$ polymorphism of interleukin- 6 gene is very rare in Koreans. Cytokine 2002;19:52-4.

35. Hedrick PW. Gametic disequilibrium measures: proceed with caution. Genetics 1987;117:331-41.

36. Maruyama T. Stochastic integrals and their application to population genetics. In: Kimura M, ed. Molecular evolution, protein polymorphism and the neutral theory. Berlin: Springer-Verlag; 1982:151-66. 